\title{
The Democratic Revolution in the USSR: Can the System Cope with Pluralism?
}

Donald R. Kelley, University of Arkansas, Fayetteville

Gorbachev's democratic revolution in the former Soviet Union fundamentally reshaped not only the political process of his nation but redefined the very nature of the nation itself. Begun as an attempt to implement guided reforms and to develop a political formula that would undercut conservative opposition, the interlocking policies of perestroika, glasnost, and demokratizatsiia acquired a life of their own, setting loose political and social forces that escaped the control of leadership at all levels. The abolition of the monopoly role of the Communist Party of the Soviet Union, the creation of democratically elected legislatures at all levels, and the proliferation of political parties and interest groups have created a truly pluralistic political system. But with such pluralism comes the need to develop mechanisms that will mediate among newly empowered political forces, finding some common ground of compromise and adjustment. In the Soviet context, four such sources of mediational activity are possible: (1) a reformed Communist Party might transform itself into a broad pro-reform coalition; (2) the newly formed political parties and groups might form broad coalitions; (3) the legislature(s) might develop mechanisms fostering the emergence of consensus; and (4) coordination might be provided by the allunion and republic presidencies. Yet even before the coup attempt, little progress had been made in finding widespread consensus, and the post-coup dispersal of power to the republic level has made the system even less likely to produce such agreement.

If there is one thing that Mikhail Sergeevich Gorbachev would probably acknowledge as true, it is that building democratic institutions is difficult business. Yet try he did, for a variety of reasons that ranged from his honest belief that Soviet society had changed so profoundly during the long years of "stagnation" that only such radical reforms could reanimate its creative forces, to his own tactical desire to offer a reform agenda that would put his opponents off guard and force them to accept his version of the future. Writing in Perestroika in 1987, he described such "restructuring" as a destructive and even "revolutionary" program (Gorbachev 1987). Neither his supporters nor his opponents today would disagree with that characterization. Gorbachev and the political forces set loose by his reforms have destroyed the Soviet Union as it was, and neither he nor any cabal of conservative forces can ever put the pieces back together in the old way.

\section{The Gorbachev Revolution: Why Did He Do It?}

Any detailed examination of Gorbachev's reform agenda should begin by placing it in perspective. Like any political formula, that agenda wedded 
Gorbachev's view of the ills and potential cures of the Soviet malaise to hardnosed concerns about political control and partisan advantage. Perestroika and the other reforms it spawned were and are not just about the reform of the Soviet system; they are also about the acquisition and maintenance of political power in the hands of a particular leader or faction. To attempt to understand them from only one perspective is to ignore the symbiotic dualism of policy and power.

When he came to power in March, 1985, Gorbachev undoubtedly knew that Soviet society was profoundly different from that extant when Brezhnev assumed the General Secretaryship in October, 1964. In one narrow sense, the Soviet Union had flourished under the eighteen years of Brezhnev's rule; it had emerged as a military superpower, commanding the respectful attention of the West in general and the Americans in particular, and the nomenklatura took no small pride in achieving parity. But in another sense, the nation was living on borrowed time. The political stability of the Brezhnev years had been purchased at the price of ignoring the need for economic and social reforms and of postponing the inevitable generational transition that would come when the generation of 1939 yielded place. More importantly, the malaise of the Brezhnev years had produced a political cynicism that ate at the moral and psychological foundations of the system. Workers pretended to work, leaders pretended to lead, and followers pretended to follow; and all knew the essential truth that lay beneath the facade: Soviet society had lost its dynamism, its hope for a better future, and its sense of a just and progressive present.

The economy had fared no better in the Brezhnev years, leaving Gorbachev to inherit not only a host of substantive problems but also a plethora of failed "solutions." To be sure, progress had been made in key areas such as military and aerospace technology, and the lot of the Soviet consumer had improved marginally at least in the early years of Brezhnev's rule. But fundamental economic problems were never addressed at the level of systemic reform. The "solution," more often than not, was to throw always-scarce investment at a problem area (agriculture is the best example), or to attempt half-hearted reforms whose consistency and prospects for success had been gutted by politically inspired compromises (the Liberman reforms, for example). By the early 1980s, even these fixes had run their course, and the economy was faced with a growing problem of food production, technological obsolescence, and worker indiscipline.

Daunting though they were, the problems of social and economic reform were less threatening than the task of political reform, or more correctly, of finding a balance between Gorbachev's personal consolidation of power, which required support within the nomenklatura, and the reform imperative, which impelled the new General Secretary to challenge the establishment even as he sought its support. Gorbachev undoubtedly knew two things very well as he pondered the complexity of this balancing act. First, he knew that his own appointment as General Secretary had not gone unopposed. A serious if ill-fated last minute attempt to block his election had been tried by a coalition of Brezhnev-era conservatives and other would-be reformers jealous of Gorbachev's power. And second, he knew that 
poorly conceived and timidly executed reforms had cost Nikita Khrushchev his post in 1964. In referring to himself as a "child of the Twentieth Party Congress," the new General Secretary acknowledged both the Khrushchevian roots of his own reform agenda and the knowledge that such changes could result in the dismissal of any political leader who failed to protect his flanks.

For the first two years he was in office, Gorbachev hoped, apparently with increasing frustration, that he could have it both ways: he could animate sufficient momentum for reform and turn the nomenklatura to his purposes and still keep control of events, avoiding the Pandoran dilemma of initiating a process of change which escaped his control. And for a while, it seemed to work; the skillful politician inside the General Secretary tacked right and left as the circumstances required, and always kept afloat. But if the politician fared well, his reforms did not, and Gorbachev increasingly found himself facing the reality that economic and social reform required political reform in at least two senses. First and more abstractly, fundamental systemic reform necessitated the alteration of the interconnected political as well as the economic and social nature of the Stalinist system. Second, effective pressures to accomplish such a transformation over the opposition of conservative forces could be mobilized only by a coalition of highly placed reformers and a newly activated and broadly democratic constituency, and that required the empowerment of grass-roots political forces that had never before played an important role in Soviet politics. To be sure, Gorbachev's vision of democracy was flawed, at least by Western standards, for he saw democratization more as an instrumental mechanism for the mobilization of the masses against his opponents and as a source of advisory feedback to a reform-minded elite than as an embodiment of the rights of the citizenry to choose their government.

Gorbachev's democratic revolution, therefore, followed the always compromised course of seeking two hopefully mutually supportive but also potentially conflicting goals: (1) to recognize the intrinsic need for democratization and to find institutional embodiments that were appropriate to the Soviet scene, and (2) to effect change in ways that worked to the political advantage of Gorbachev and his reform forces. Democratization and the pluralism that had to be accepted if it were to occur were to be means to a specific end: the further consolidation of Gorbachev's power over conservative forces and the attainment of the other elements of his reform agenda. Pressures for internal democratization within the Communist Party, the creation of a new two-level legislature in the Congress of People's Deputies and the Supreme Soviet, the revocation of Article Six of the constitution which had established the political monopoly of the CPSU, the tolerance and then legalization of informal lobbies and new political parties, the creation of a strong, although not yet directly elected presidency, and the proffered revision of the union treaty to permit greater autonomy for non-Russians all were intended to institutionalize a new form of Soviet pluralism while simultaneously creating a political milieu within which reform forces could mobilize popular support. The answer to how and why this particular single-party state embraced pluralism is simple: its leaders scrapped 
the institutional and political guarantees that had preserved single-party rule, at first not because of popular agitation or pressure from alternative democratically inclined elites who challenged them for the right to rule, but rather because they (or perhaps only Gorbachev) sincerely believed that such changes would give them malleable weapons with which to accomplish the other goals of their reform agenda. Consistent with Soviet and earlier Russian history, change -- even the most benevolent and well-meaning -- came from above, in the company of the hubris of a political elite that assumed that it knew best and that it could control events.

But if Gorbachev and the reformers around him understood the "proper" combination of elitism and democracy that would lead to reforms, they clearly underestimated the degree of change within Soviet society that these new policies would produce. With increasing force, the General Secretary spoke of the need to build a "civil society," meaning that the individual citizens (and eventually the groups and parties within which they would coalesce) would be mobilized into willing participant-reformers, aware of their newly acquired role in the democratic order but also cognizant of the limits of democratization and of their own apprenticeship to the leadership. What neither expected was the three-fold revolution of rising expectations in politics, the economy, and cultural life that generated increasing demands on the already fragile institutions, the emergence of alternative elites and potential leaders (especially among the democrats), and the collapse of both elite and public trust in the institutions of Soviet rule.

\section{Gorbachev's Democracy: Can Consensus Emerge from Pluralism?}

There is no question that it is now possible to speak of a behavioral, if not yet institutionalized, pluralism in Soviet politics -- a pluralism going well beyond that envisioned in the first years of Gorbachev's tenure in office, when hopeful reformers spoke of the possibility of greater flexibility within the framework of a modified oneparty system. The rules have changed, and although the concatenation of events is familiar to anyone who has followed Soviet politics over the last several years, it bears at least quick repetition because of the cumulative impact of events. The Communist Party of the Soviet Union, once the "leading core" of the system, is virtually defunct as a consequence of the August, 1991 coup attempt, deprived of its property throughout the nation, prevented from conducting grassroots activities at the factory or institutional level, and banned outright within the Russian republic. Even before August, it had shattered into squabbling factions, some representing various ethnic territories through a de facto federalization of the party, some reflecting the growing ideological diversity of a party desperately trying to find a role in society, some attempting to cling to former institutionalized mechanisms of rule, and some simply following real or would-be charismatic leaders. New political parties running the gamut from monarchists to "true" Marxists have formed as a consequence of the revocation of Article Six of the constitution and the passage of a new law permitting the creation of political organizations. Informal political 
organizations, now numbering well over 60,000 , have sprung into existence, sometimes dealing with single issues such as local concerns or the environment and sometimes forming broader coalitions with other parties and organizations. Loosely united coalitions of parties and informal groups have emerged in the form of popular fronts. Before the creation of an interim government after August, factions had already formed within the short-lived two-level legislature, with coalitions such as the Interregional Group of Deputies or Soyuz representing pro-reform or conservative elements. In addition, "street politics" has become an important element in the feuding of competing factions and parties, as witnessed in the outpouring of anticoup sentiment in Moscow, Leningrad (as it was still known then), and other cities. And perhaps most importantly, effective political power has shifted from the central government to regional authorities.

But to acknowledge the existence of such pluralism is not accurately to portray the Soviet Union-cum-Commonwealth of Independent States as a true multiparty system -- at least inasmuch as that description commonly implies that the party structures channel political conflict, accurately reflect the views of and speak for particular constituencies, and take part in the functioning of government or opposition. In many ways, the evolution of the party and group structures has not reached that level of maturity. Having stressed the politically easier task of articulating the views of constituencies which in many cases they hope to activate, parties and groups have given less emphasis to their own internal organization and the creation of effective campaigning and electoral mechanisms.

The new pluralism must also be explained, at least in part, in terms of the purposeful devolution of real political power throughout the system. While always de jure federal, the Soviet Union under the old order was, de facto, a highly centralized political-administrative structure. That had begun to change even before the August coup attempt. Both the geographic devolution of power and authority downward to republic- and local-level bodies and the lateral dispersal of power at all levels through the creation of more powerful legislatures and presidential offices established multiple points of access to decision makers. The formation of such new institutions and/or the empowerment of formerly rubberstamp bodies have had the predictable effect of animating political forces whose activities are targeted at these newly powerful entities.

The situation was further complicated by the widespread uncertainty about who was to decide what. Was economic or social policy to be made at the all-union level as before, or were each of the republics or the major cities to decide their own priorities in consultation with, or in complete isolation from Moscow? The tendency to shift the focus of political agitation away from the inherently more conservative (or perhaps merely more distant) central institutions in Moscow to the republic or local levels was strengthened by the relative ease with which local coalitions dislodged the formerly entrenched party and state establishments.

The attempted coup, undertaken on the eve of the signing of the new union treaty that would have extended greater power to the union republics while 
maintaining a viable center, rapidly accelerated this process of dispersal. The postcoup backlash led to a crippling of Gorbachev's all-union presidency, to the creation of interim legislative and executive institutions (see below), to the promise to draft a new constitution and an even less centralized union or confederation treaty, and ultimately to outright independence for the Baltic states and the Ukraine. Just as significantly, the coup destroyed what little sense of hope remained that the transition to democratic institutions and a market economy could be managed without economic collapse and social disintegration. That the Commonwealth of Independent States - formerly the Soviet Union -- was now pluralistic was unquestionable; whether such pluralism could be successfully institutionalized and channeled into governable form remained open to frequently contentious debate.

\section{Pluralism and Beyond: Representation and Order}

If Mikhail Gorbachev's political reforms are to be assessed in terms of mobilizing new political actors and broadening the range of political discourse, then they must be judged an unbridled, if cacophonous success. At first change came slowly, with the caveat that the party would preserve a special role, if not its old "leading role," in the political process. It was to transform itself into a broader political coalition, leading non-party elements by example and coopting, as it always had, the best and the brightest of the new politicians. It was to lead through its role in popular fronts, which would link the CPSU to other parties and to the growing array of informal groups. And finally, it was to win its leadership role through the ballot box, transforming itself into a parliamentary party both in the sense that it won popular approval through the electoral process and in the sense that it formed a coherent working parliamentary bloc within the legislature. According to the February, 1990 Central Committee plenum, it was to continue to perform a "unifying" and "consolidating" role within the new pluralistic political environment, functioning "strictly within the framework of the democratic process" (Pravda 6 February 1990).

But Gorbachev's and the party's best plans went astray. Careful and controlled pluralization quickly gave way to a less well defined, less guided process. At times, the General Secretary himself accelerated the pace of change as a weapon against his opponents, especially within the conservative apparatus. What had begun as a campaign to transform the party quickly became a process of supplanting it, in part with the mechanisms of elected democratic institutions and in part with the creation of a strong national presidency. The party, and eventually the new presidency itself, lost control of the two key elements that had preserved order in the past: control over the political agenda, and veto power over the creation of alternative political institutions.

Adding to the disorder even before the coup attempt was the factionalization of the CPSU itself along regional and ideological lines. National party leaders were compelled to accept the de facto federalization of the party. The growing 
assertiveness of non-Russian republics led to the creation of nativist and proMoscow wings of once unified local communist party organizations, themselves either replaced at the helm by non-communist popular fronts, or pressured by such to chart a course different from that dictated by the center. The creation of executive presidencies patterned after Gorbachev's office in each of the republics further complicated the party's dilemma. Of the fifteen presidents in office just before the coup attempt, six were political independents with ties to nationalist popular fronts or non-communist political groups, three were titular party leaders who worked closely with such fronts or parties, and only six were considered pro-Moscow (The Economist 24 November 1990).

The creation of a separate communist party for the Russian republic also complicated Moscow's task and further accelerated the separatist tendencies of the region. Except for a brief period under Khrushchev, the Russian republic party organizations were administered directly by the central party apparatus, a mechanism that ensured their loyalty. The initial call for the creation of a separate organization came from conservatives in Leningrad who hoped that it might provide a counterweight to Gorbachev's more liberal leanings. Gorbachev countered with a proposal to create a separate Bureau for the Russian Republic -- the Khrushchev ploy -- but by September, 1989, pressures for the formation of a separate republiclevel party organization had grown (Pravda 21 June 1990; Teague and Tolz 1990, 1-3). The formal creation of the separate party organization occurred in June, 1990, and its first secretary (who must be distinguished from the better known head of the Russian republic's government, Boris Yeltsin) was Ivan Polozkov, a conservative party leader (Gruber 1990, 29-38). In one sense, the formation of the Russian republic organization made the party even more vulnerable after the August coup attempt. Seizing upon a moment when the national party was at its weakest and his own personal popularity was at its greatest because of his role in thwarting the coup, Yeltsin suspended all party activities within the republic, took control of all party property (including the Central Committee building on Old Square, which now houses his personal staff), and eventually formally outlawed the party.

Other factions abounded within the national party even before August, including: (1) the Leningrad Initiative Group, which advocated a defense of Russian economic interests within the union, a vanguard role (the old definition, we must presume) for the Communist Party, and anti-market reforms of the economy; (2) the Democratic Platform of the Communist Party of the Soviet Union, which called for a two-stage transition to democratic socialism, the democratization of the party, the renunciation of dogmatic Marxism, the admission of the party's responsibility for the creation of a totalitarian system, and the transformation of the CPSU into a parliamentary party working within a multiparty system; (3) the Marxist Platform of the CPSU, which sought a restoration of public confidence in the party through the dismantling of the apparatus, the development of self-management, and the transformation of informal political organizations into important participants in government and administration; (4) the Union of Constitutional Communist 
Democrats, which argued for the reunification of party and society through the creation of a government based on the rule of law, the creation of separate branches of government, freedom of expression, and the creation of a multiparty system within which the Communist Democrats would form the leadership of coalition governments within the soviets at all levels; and (5) the Moscow Party Club, which advocated democratic reform within the party, political pluralism and a multiparty system, an end to democratic centralism (that is, internal party discipline), and the development of a market economy (Gruber 1990, 31-36).

The abolition of the CPSU's constitutionally mandated status as the only legitimate political party opened the door for the creation of a plethora of new organizations. In the first six months after the revocation of Article Six, more than one hundred political parties and other organizations were formed, with over twenty claiming to be active at the all-union level (Meerovich 24 August 1990, 8-16). But it is also important to understand what these new parties are not and what they cannot do. For the most part, they remain small organizations without organized and mobilized constituencies. Only a very few, such as the Democratic Party in the Russian republic, have electoral mechanisms designed to communicate with voters, select candidates, and conduct campaigns. Fewer still offer coherent and specific platforms on a wide assortment of issues. Eloquent about the general state of affairs they wish to see created (or, conversely, avoided), such platforms usually offer few specifics. Symbolic issues -- democratization, freedom of speech, and the like -- are the common fare, and difficult economic issues are avoided or at best deflected with generalizations for or against marketization.

The leadership of these parties also leaves much to be desired. To be sure, there is no reason to expect that skilled political leaders would emerge to guide this new assortment of parties; democratization has become a learn-by-doing process in the Soviet Union/Commonwealth. But even with such allowances, it remains apparent that the parties frequently are merely extensions of a particular leader or group of leaders. Personalities as much as platforms govern the ebb and flow of party cohesion and factionalism, and questions of building broad coalitions and a viable electoral base of support seem to occupy lower priority than the dominance of a particular party leader. Moreover, key leaders, and especially those who have assumed the presidencies of the newly empowered republics, have distanced themselves from party ties. In so many words, politics are personalized and candidate-centered in a manner reminiscent of the South that Key wrote about.

While the creation of political parties has fundamentally altered the political landscape and contributed to the expansion of the representational aspects of the system, the formation and growth of informal political associations -- simply termed "informals" -- has further led to the proliferation of political actors. Such "informals" are best conceptualized in Western terms as functioning much as interest groups, political action committees, and the plethora of single-issue groups that have changed the political process in most democracies. Even before their legalization in 1990, they grew like the proverbial mushrooms after the rain, 
responding to the new freedom for political discussion created by glasnost and filling the void that existed in a political culture in which there had been few organizations to mediate between the individual and political institutions. Given added impetus by democratization, they raised new issues, in many instances fielded candidates for election, joined in usually loosely united coalitions on questions of national or local importance, and -- perhaps most importantly -- served as the first introduction to the new democracy for many formerly inactive citizens. By the end of 1989 , over 60,000 such groups were estimated to be functioning, ranging from single-issue groups concerned with questions of the environment, historical preservation, the rehabilitation of the victims of political repression, and the like, to broader orientations dealing with more sweeping reform issues. Even more importantly, their rapid growth was marked both by a process of politicization and by halting attempts to form ties among themselves to create viable popular fronts or political parties. While the latter efforts have been less than successful, except under special circumstances in which local issues such as regional independence have created a common ground, these groups have stretched the boundaries of the political system, legitimating new issues and adding both to the level of true representation and to the decibel level of the debate (Tolz 24 November 1989, 4-7).

At first, Soviet leaders encouraged the emergence of such groups and sought to channel their efforts along acceptable lines. By 1988, however, the informals had transformed themselves from a collection of relatively apolitical debating societies talking about safe issues to increasingly militant and vocal political action committees. By 1990 the leadership's attitude had changed. Policy shifted from support and amazed tolerance to scrutiny and closer supervision, and party grassroots organizations were instructed to infiltrate and guide such informal associations (Tolz 23 September 1987, 30 October 1988, and 9 March 1990; Brovkin 1990, 233-57).

Official encouragement for the formation of popular fronts also added to the growing pluralism. Initially thought of as umbrella groups whose coalition-building would mediate the impact of the growing number of informal groups and lead to a spirit of compromise and moderation, the popular fronts were to form broad alliances linked by the acceptance of common themes and policies. Among the first were a series of pro-reform or pro-perestroika groups that united fledgling democratic forces. By the end of the decade, their goals had changed, in part as a consequence of the growing radicalization of political life and the polarization of conservative and pro-reform forces, and in part because the most successful fronts coalesced around disruptive issues, especially the questions of national self-determination and independence. While the most notable -- and potentially disruptive -- fronts emerged in the Baltic states, similar developments occurred throughout the Soviet Union. Finding their source of unity in real and imagined mistreatment by central authorities and in the growing desire for a redefinition of the union treaty, these fronts formed viable coalitions at the regional level, bridging the differences that separated local political forces, but at the expense of raising extremely disruptive issues at the 
national level (Vardys 1989; Senn 1990).

Although they had already established a firm de facto presence, the new parties, informals, and popular fronts lacked a formal legal basis for their existence and activities. While Gorbachev had promised the passage of a new law on political associations since 1987, conflicts over the actual content of the legislation and whether informal groups and political parties should be treated differently delayed action. No fewer than four drafts of the law were presented from 1987 to 1990, with each subsequent draft loosening restrictions (Meerovich 13 July 1990, 6-8).

Final passage of the law on public associations came in October, 1990, and the preamble paid due respect to Gorbachev's desire to create a "civil society" of competent political activists (Pravda 16 October 1990). Broadly mandated to act "for purposes of the exercise and protection of civil, political, economic, social and cultural rights and liberties," they are authorized to carry out any activities "not prohibited by law." However, associations may not advocate the "overthrow of or violent change in the constitutional system or the forcible violation of the unity of the USSR," nor may they conduct "propaganda for war," stir up "social discord," or advocate the "commission of other criminally punishable acts ...."

\section{Finding Agreement: Can the System Manage Pluralism?}

While the foregoing analysis leads to the conclusion that recent political reforms score high marks in terms of expanding and institutionalizing the representational aspects of the system -- that is, broadening the boundaries of political debate and institutionalizing mechanisms through which such discourse occurs -- it is far less certain that demokratizatsiia has as successfully provided processes and mechanisms through which agreement and compromise may emerge. In one sense, of course, any movement away from a single-party toward a multiparty system complicates the task of interest aggregation. Whatever its other liabilities, the CPSU was the ultimate aggregator. The question now arises whether the new mechanisms can perform that aggregational function.

Answering that question is a far from simple task, especially since the attempted coup and the abolition of the institutions of the Soviet state. Even before that flawed effort to block the signing of the new union treaty accelerated the shift of power from the center to the republic level, there were few institutional sources of such mediational activity. To be sure, Gorbachev and the dwindling number of reformers associated with the central government hoped that the Communist Party itself might lead democratically through the new political arrangements, especially if (and it was a big if) the all-union presidency were in the hands of moderate centrist reformers. Others such as Alexander Yakovlev and Eduard Shevardnadze hoped to form an umbrella reformist party linking liberal elements of the Communist Party itself with non-party (or ex-party) activists. But on the eve of the coup attempt, the prospects that effective coordination and mediation might occur seemed removed. Only four sources of such activity seemed possible: (1) as noted, a reform 
Communist Party could lead democratically through freely elected institutions; (2) the new political parties, informal groups, and popular fronts could find common ground and bridge the personal, ideological, and regional differences that separated them, forming effective coalitions in the pre-electoral phase or within the legislatures; (3) the legislatures themselves could provide effective internal mechanisms leading to the emergence of such consensus; and/or (4) coordination could emerge through the growing strength of the all-union presidency, through the use of emergency powers willingly granted by a self-doubting legislature, through the prestige of the office itself, or through the interaction of the all-union and regional presidencies. The coup attempt in August and the collapse of the central government in December introduced a new dimension which must be added to this less-thanhopeful list: the task of coordination would be fundamentally redefined by the creation of a vaguely defined commonwealth and the destruction of the all-union presidency, raising the question of mediation not only within the multiple and increasingly complex republican settings but also among sovereign states joined in a looser and as yet poorly defined association.

A reformed Communist Party could lead through the new institutions. It was a nice theory, while it lasted. In its most optimistic form before August, this scenario held forth the possibility that the CPSU might transform itself into a parliamentary party along the lines suggested by Gorbachev at the February, 1990 Central Committee plenum. Although stripped of its constitutionally mandated grip on power, the party would still remain the nation's leading political force because of its ability to mobilize support for further reform. It would legitimate its leadership both through the ballot box and -- as it had always claimed in the past -- through the indispensable guidance provided by the party's best and brightest cadres who continued to hold important decision-making positions at all levels of the system. Formally separated from the day-to-day concerns of governance, the party would be free, as it never had been in the past, to offer overall leadership on important questions of policy. It would form a broad coalition at all levels, linking reform elements within the party itself to a broader grassroots pro-reform constituency, which it could mobilize against conservative forces.

The success of such a scenario depended on two far-fetched conditions. First, the party itself would have had to accept the reform mandate offered by Gorbachev, setting aside (at least temporarily) the short-term concerns of institutional prerogatives and personal power. Second, the broader grassroots constituency upon which the party would have depended for its continuance in power through the ballot box would have had to respond positively to the proffered leadership.

Even a cursory examination of the party's fate under Gorbachev indicates that this scenario seemed unlikely to materialize even before the coup. While Gorbachev must be given high marks for attempting to transform the party, the transfer of important decision-making powers to the presidency confirmed that the party's actual influence over events had waned. Serious and perhaps insurmountable problems existed both within the party itself and in its relationship with the broader 
constituency which it hoped to mobilize. At all levels, the party was internally divided not only over the basic orientation to perestroika and the other aspects of Gorbachev's reforms but also over the increasingly strident question of local autonomy and/or independence. As an all-union political force, the party had lost both its sense of unified direction and the political clout of a tightly disciplined political machine operating through the apparatus and the control of the nomenklatura.

In part because of Gorbachev's sweeping personnel changes within higher party bodies and his politically motivated restructuring of virtually all command structures (the Politburo and the Secretariat had already lost virtually all of their ability to shape events on a day-to-day basis, and the Central Committee had been reduced to a hollow debating forum), and in part because the party itself had bitterly split over the issue of reform (avoiding an open rupture at the Twenty-eighth Party Congress only because disaffected elements chose to abandon the party rather than split it), the CPSU had not responded to the General Secretary's attempts to recast it as a parliamentary party leading a wide coalition of reform forces. Even where it had sought to embrace the reform agenda -- as in the Baltic states, where significant portions of the existing party leadership attempted to place themselves at the head of pro-reform forces -- the party already had been seriously challenged and in most instances deprived of its majority in republic and local elected bodies by non-party popular fronts and newly created political parties.

The grassroots public support which Gorbachev had hoped to mobilize in tandem with reforms within the party itself also failed to materialize, or eventually abandoned the CPSU in favor of more radical parties or leaders. What had begun as a hopeful balance between admitting the party's past errors and filling in the "blank pages" of Soviet history on the one hand and the reconstruction of a viable and attractive "new" parliamentary party on the other had become, even before the coup attempt, an orgy of rejection and recrimination.

Yet, despite the attacks of its opponents and its own factionalism and selfdoubt, the CPSU still remained (before the coup attempt) the best organized political force in the nation, led by a charismatic, if controversial, General Secretary whose boldness and political skill averted a formal split in the face of mounting internal divisions. Although weakened by a growing number of resignations and challenged openly by regional leaders (such as Yeltsin) who sought to end the activities of primary party organizations at the grassroots level, the party still maintained a loyal following throughout the state bureaucracy. While discredited, the nomenklatura remained the best political machine in town, and although it had suffered significant losses at the polling booth, it still commanded an extensive network of operatives in all aspects of Soviet society. Moreover, at the regional and local levels, its prospects for winning some share of power legitimately through the ballot box curiously were enhanced by the fate of perestroika. Even its opponents acknowledged its continuing strength, and Yeltsin postponed local elections within the Russian republic scheduled for early December, 1991, when it became apparent that local party officials would win in a majority of cases (Teague and Tolz 22 November 
1991). Even within the national legislature that existed until December, 1991, the party had been chastised but not yet routed. Responding to a poll taken before the coup that asked deputies to the Congress of People's Deputies to identify their institutional loyalties, 730 deputies, or nearly a third of the total membership, listed themselves as first and foremost belonging to the CPSU bloc. In contrast, the loosely organized conservative bloc, Soyuz, numbered only 561 members, while the even more poorly disciplined pro-reform Interregional Group of Deputies found support among only 229 legislators (Vremya 24 December 1990; Radio Liberty 24 January 1991).

The coup and subsequent events changed all that. Although the State Committee for the State of Emergency in the USSR that led the abortive coup was hardly exclusively a party body, the party itself bore the lion's share of public rejection after the failure of the attempt to seize power. To be sure, at least initially, Gorbachev would have had it differently. Returning from house arrest and isolation in Foros, he attempted to separate the plotters from what he believed to be the vast bulk of party members who endorsed reforms. Perhaps hoping to salvage a role for a CPSU now to be purged of its conservative elements and to redefine the party along social democratic lines before the next election, he at first argued that the party should not be blamed in toto for the attempted coup. Within days, however, Gorbachev was sobered by pressure from anti-party leaders such as Yeltsin and the realization that the party apparat had supported the coup or bided its time on the sidelines. He resigned the post of General Secretary, called for the resignation of the Central Committee, approved the transfer of party assets to regional and local soviets (thus striking the killing blow against the nomenklatura), and sanctioned the de facto and eventually de jure suspension of all party activities, from the grassroots to the Kremlin itself. While there have been halting attempts to revive the party under a new label (involving figures as different as Alexander Rutskoi, head of the newly created Democratic Party of Free Russia, Nina Andreeva, the Stalinist founder of the All-Russian Communist Party, and the former dissident Roy Medvedev, now associated with the Socialist Party of Working People), the party of Lenin was no more (Teague and Tolz 22 November 1991, 1-8).

Newly formed political parties, informal groups, and popular fronts will coordinate policy. This second scenario holds forth the possibility that the newly formed political parties, informal groups, and popular fronts might find the political will and the mechanisms through which to broker their divergent interests. Such compromise could occur either in the pre-electoral environment, through the formation of permanent or floating coalitions, or within the legislative environment through coalition governments. Several preconditions would need to be met before such mechanisms could channel political conflict. First, the parties themselves would have to develop a clearer sense of self-identity and purpose. At present, their platforms typically consist of vague generalities, dealing more with procedural issues or general strategies of economic reform than with specific allocational and distributive priorities. 
Second, the parties themselves would have to evidence greater willingness to compromise their differences over both policy and the more immediate questions of leadership. If the first two years of Soviet democracy have been an accurate lesson, we may expect the continued proliferation of smaller and specialized parties, and the splintering of existing parties because of factional disputes over policy or leadership issues.

Third, successful brokerage in the pre-electoral phase would require that existing parties create formal or tacit alliances or offer common platforms and slates of candidates. To date, efforts to create such alliances have largely proven futile, breaking down over predictable issues of leadership and policy.

Reviewing the formation of such small and disunited parties, one commentator has noted that the situation should be described "not as partiinost, the development of genuine parties, but as portsialnost, the battle of ideological groups lacking a real social base" (Meerovich 24 August 1990). Citing Soviet sociologists' characterization of such parties as "protoparties," he observed they have been formed on

the basis of populist, ideological, or charismatic impulses common to their members; their numbers are small, their organizations are weak and prone to internal splitting; and their programs are undeveloped and show only rudimentary ideological differences, with a marked opposition to the current state of affairs their most common feature (Meerovich 24 August 1990, 10).

The formation of such coalitions seems most difficult among the democratic parties; while they share common agreement about the need to preserve democracy, they divide on the nature of the threat to the preservation of the new order and on the inevitable question of who should lead such a coalition. Attempts to form an alliance of democratic forces have floundered. A conference of all "generally democratic" forces held in Kharkov in late January, 1991 to create a Congress of Democratic Forces produced only partial agreement (Tolz 8 February 1991, 6-8). Other attempts to bond together nascent democratic forces have also yielded only marginal results. Within the Russian republic itself, three of the major democratic parties -- the Democratic Party of Russia, the Social Democratic Party of Russia, and the Democratic Platform -- participated in the creation of a Democratic Russia front, which attempted until its breakup late in 1991 to create grassroots organizations in the major cities of the RSFSR. But despite general agreement that unity is desirable, no concrete steps have been taken to move toward a formal consolidation of the movement or to integrate the parties into a single organization (McFaul 18 January 1991, 6-9).

Yet another attempt to form a pro-reform coalition of democratic forces occurred in the summer of 1991, only months before the attempted coup. Led by Gorbachev's former close associates Alexander Yakovlev and Eduard Shevardnadze, both of whom had broken with the president over the lagging pace of democratic reforms, the new Democratic Reform Movement was meant to be an umbrella 
organization uniting disaffected party members with the centrist democratic parties that had emerged in the Russian republic and elsewhere. Gorbachev himself lauded its formation, in part because by the early summer he had again moved to the center of the shifting political spectrum, and in part perhaps because he saw it as a possible institutional home if he should someday (as he had already threatened) wish to resign from the CPSU General Secretaryship.

While the parties per se seem ill-prepared to perform such brokerage activity, the popular fronts that have typically emerged in the non-Russian areas have fared far better, at least for the narrow range of issues around which such coalitions have formed. Before August, such popular fronts existed in virtually all republics and in the majority of autonomous republics and provinces. Within the Russian republic, an estimated 140 such fronts had been set up in cities and regions, with some winning control of local elected bodies (Tolz 27 April 1990). Because of their very nature as broad-based coalitions that placed the question of national identity and greater autonomy and/or independence ahead of other considerations, they bridged gaps and survived internal leadership squabbles that would have split more conventional parties. But in one sense, their strength is also their weakness, at least in terms of brokerage, especially now that power has shifted to sovereign republic institutions. Before the destruction of Moscow's authority, such fronts were principally concerned with center-periphery issues and tended to deemphasize other critically important issues such as economic reform, except where such issues could be turned against Moscow's erstwhile control. But when popular fronts emerged as ruling coalitions following the coup attempt, the "natural" issue of greater autonomy or independence disappeared, forcing them to deal with difficult and divisive issues of economic and social reform that divided a constituency once united on the question of opposing Moscow's control.

The attempts by political parties and popular fronts to move toward some clear definition of political forces have been made more difficult by the parties' own declining sense of effectiveness within the legislature and by the growing disaffection of the average citizen with a democratic process that seems unable to confront the nation's problems. At the all-union level, legislative sessions before August were marked both by the increasing militancy of democratic forces and by the legislature's willingness to vote even greater emergency powers to the presidency (Pravda 16 March 1990; Mann 23 March 1990, 1-4; Teague 23 March 1990, 6-7). And at the republic and local levels, if the Russian republic's parliament and the Moscow city soviet are good examples, legislative bodies have substituted debate for meaningful action.

The possibility also exists that the so-called "informals" will coalesce into working coalitions. Clearly among the most prolific of new political entities, such groups could enjoy several distinct advantages. First, because of their typical single-issue focus, they can exploit the image of being "above politics," at least insofar as that perception would distance them from the growing criticism of the larger (and less disciplined) political parties and popular fronts. Second, they at least 
have the potential of mobilizing political forces beyond the reach of the existing political process, especially if they are able to present themselves as concerned with issues and policy outcomes rather than the mere struggle for power. Third -- and this may be an important advantage -- they represent a wholly new form of political organization within the Soviet context. Their very uniqueness may be one of their greatest strengths, at least in terms of mobilizing public support.

Yet, by their very nature, such groups will tend to further subdivide the political spectrum, especially insofar as their single-minded focus on a particular issue, no matter how significant and laudable in its own right, makes it difficult to create more broadly based coalitions. If the American experience with such groups is any indication, we may anticipate that the proliferation of informals may help forestall any shared substantive consensus except on the most general procedural issues such as democratization and glasnost. Increasing activity by such groups will lead to the creation of multiple, intensely committed constituencies with few overlapping interests or membership. Single-issue politics will introduce a punitive orientation (if you do not support our group on its issue of choice, then we will oppose you regardless of your position on other issues) that makes the task of political calculation a matter of weighing the comparative power of intensely motivated advocacy and veto groups.

The militancy of such single-issue informals is likely to intensify as the political agenda shifts from symbolic and participational issues, on which such groups can more easily find agreement, to distributive and allocative issues that will bitterly divide the community as the costs and benefits of political and economic reform are meted out throughout the society. The likely increase in so-called "entitlement issues"-- one's "right" to national self-determination, a clean environment, or a decent standard of living -- will also complicate the task of finding compromise.

Coordinating mechanisms will emerge within the legislatures themselves. It is also possible that mechanisms will emerge within legislative bodies at the national and regional levels, although any discussion must reflect uncertainty about the structure of the commonwealth government and the likelihood that real power will remain in the hands of regional officials now recast as the leaders of independent states. Coordination might emerge through three mechanisms typical to other multiparty parliamentary systems: (1) the emergence of coalition governments in the post-electoral phase, especially insofar as the creation of a legislative majority (however shifting and temporary) becomes the key to power within the legislature; (2) the creation of parliamentary blocs falling short of formal coalition governments; and (3) the formation of procedural mechanisms, most likely through the creation of a viable and depoliticized committee structure, that produce de facto agreements.

Even before August, the creation of bona fide coalition governments seemed unlikely at the all-union level, although the mechanisms by which deputies to the Congress of People's Deputies were selected in the first round of the election/ selection process were intended to produce what was presumed to be a stable core of representatives of the existing establishment. Since one third of the Congress 
have the potential of mobilizing political forces beyond the reach of the existing political process, especially if they are able to present themselves as concerned with issues and policy outcomes rather than the mere struggle for power. Third -- and this may be an important advantage -- they represent a wholly new form of political organization within the Soviet context. Their very uniqueness may be one of their greatest strengths, at least in terms of mobilizing public support.

Yet, by their very nature, such groups will tend to further subdivide the political spectrum, especially insofar as their single-minded focus on a particular issue, no matter how significant and laudable in its own right, makes it difficult to create more broadly based coalitions. If the American experience with such groups is any indication, we may anticipate that the proliferation of informals may help forestall any shared substantive consensus except on the most general procedural issues such as democratization and glasnost. Increasing activity by such groups will lead to the creation of multiple, intensely committed constituencies with few overlapping interests or membership. Single-issue politics will introduce a punitive orientation (if you do not support our group on its issue of choice, then we will oppose you regardless of your position on other issues) that makes the task of political calculation a matter of weighing the comparative power of intensely motivated advocacy and veto groups.

The militancy of such single-issue informals is likely to intensify as the political agenda shifts from symbolic and participational issues, on which such groups can more easily find agreement, to distributive and allocative issues that will bitterly divide the community as the costs and benefits of political and economic reform are meted out throughout the society. The likely increase in so-called "entitlement issues"-- one's "right" to national self-determination, a clean environment, or a decent standard of living -- will also complicate the task of finding compromise.

Coordinating mechanisms will emerge within the legislatures themselves. It is also possible that mechanisms will emerge within legislative bodies at the national and regional levels, although any discussion must reflect uncertainty about the structure of the commonwealth government and the likelihood that real power will remain in the hands of regional officials now recast as the leaders of independent states. Coordination might emerge through three mechanisms typical to other multiparty parliamentary systems: (1) the emergence of coalition governments in the post-electoral phase, especially insofar as the creation of a legislative majority (however shifting and temporary) becomes the key to power within the legislature; (2) the creation of parliamentary blocs falling short of formal coalition governments; and (3) the formation of procedural mechanisms, most likely through the creation of a viable and depoliticized committee structure, that produce de facto agreements.

Even before August, the creation of bona fide coalition governments seemed unlikely at the all-union level, although the mechanisms by which deputies to the Congress of People's Deputies were selected in the first round of the election/ selection process were intended to produce what was presumed to be a stable core of representatives of the existing establishment. Since one third of the Congress 
deputies ( 750 of the total 2250 ) were to be chosen by the institutions rather than by direct popular election, there was a strong presumption that they would respond less willingly to grassroots pressures. This is not to argue, of course, that such institutions eventually might not have selected representatives who were themselves as reformist, or even more radical than those selected from normal geographic constituencies. The results of the first round of such institutionally based elections produced mixed results, with elements such as the Communist Party selecting centrist and conservative delegates, while other institutions such as the Academy of Sciences returned reformist candidates.

Under the pre-coup arrangements, the process through which deputies to the Congress of People's Deputies were chosen for membership in the Supreme Soviet was also intended to slow and filter the direct exercise of popular will. From among their own number (including the 750 delegates representing institutions), the deputies chose 542 delegates for membership in the bicameral Supreme Soviet. Even if it is assumed that the legislators chosen for membership in the higher body would have faithfully mirrored the political divisions of the lower house, the overall effect would have tended toward the selection of less radical delegates.

In the second instance, the creation of parliamentary blocs had already begun to occur before August, with some such as the Interregional Group of Deputies, the principal liberal coalition, and Soyuz, its conservative counterpart, playing important roles in structuring the debate, if not in the flow of legislation. The Interregional Group is an instructive example of both the strengths and weaknesses of such formations. Founded in July, 1989 at the first session of the Congress of People's Deputies, the Interregional Group was designed to gather together into one faction all of the deputies who advocated democratic reform. Its original leadership included notables such as Boris Yeltsin, Andrei Sakharov, and Yuri Afanasev, and it quickly became the major spokesman for the democratic opposition to Gorbachev's "aggressively obedient majority" within the legislature. It took the lead in the organization of Democratic Russia, its counterpart group within the Russian republic's legislature. Despite these accomplishments, the Interregional Group failed to emerge as a full-fledged parliamentary opposition. It remained internally divided over key questions of economic reform, the fate of the all-union government, and the powers to be granted to Gorbachev's strengthened presidency. Key leaders -- especially Yeltsin since his break with the CPSU -- remained aloof from complete identification with the group, using it instead as a sounding board for their personal positions and attacks on Gorbachev. Moreover, the Interregional Group failed to develop extra-parliamentary mechanisms through the formation of grassroots political organizations (Rahr 26 October 1990, 1-4).

Similar intra-parliamentary groups existed at the national level. Within the Congress of People's Deputies, membership in such groups was widespread, with deputies officially registering as members of eighteen factions, and sometimes as members of more than one group. As noted above, the largest group remained the bloc of CPSU loyalists, who constituted 730 members. The conservative Soyuz 
power, consisting of the all-union president (Gorbachev) and the chief executives of the republics wishing to remain within the union (a union, to be sure, that was undefined at the time of the creation of the State Council itself). Predictably, Gorbachev and the headstrong leaders of the republics quickly clashed over the authority vested in the Council, the remaining powers of the all-union presidency, and interpretations of the nature of future federated, confederated, or commonwealth ties linking some, if not all, of the now sovereign republics.

Economic and social planning was lodged in the hands of the Interrepublican Economic Committee, whose chair was to be named by the all-union president and whose other members were chosen by republic level authorities. Charged with determining the mechanisms of economic cooperation among the now sovereign republics, the committee faced the daunting task of developing a framework for maintaining some form of economic cooperation in the face of growing economic chaos and the politically irresistible temptation to place local economic priorities ahead of those of other regions or of the union as a whole. By November, 1991, a tentative agreement was reached including ten of the remaining twelve republics. It provided for the creation of a free market, private property, privatization of state owned assets, a single banking system, a national currency, and an all-union budget, albeit it a small one. Up to twenty separate enabling agreements will be needed to implement the specific features of the accord. Even before work could begin on these details, economic strains quickly emerged. The Ukraine insisted on its right to issue its own currency, and the Russian republic moved rapidly to claim all-union resources and to cut off funds to all-union agencies.

Interim legislative arrangements were equally ill-equipped to coordinate the activities of the republic governments. Cast into limbo both by its tardy response to the coup attempt and by an early agreement between Gorbachev and Yeltsin to shift effective power to the State Council, the Supreme Soviet was stripped of any mandate. More importantly, real power shifted to the republic legislatures, which asserted their own growing independence, sometimes pressuring regional presidents to take less cooperative positions toward the center (the independence-minded Ukrainian parliament, for example), and sometimes undercutting the efforts of these executives to rule by decree (the Russian parliament's refusal to support Yeltsin's efforts to take control of events in the breakaway Chechin-Ingush region, for example).

Looking beyond these interim arrangements, the prospects that any newly created national legislature might play a coordinating and mediating role appear bleak. At the center, the exact shape of the institutions of the Commonwealth of Independent States, formed by the agreement of eleven of the USSR's former republics in December, 1991, remains uncertain. It seems reasonable to conclude, however, that any legislative and/or other policy-making bodies would be indirectly chosen by the respective local authorities, and enjoy few if any real powers. Moreover, the declining importance of a supra-republican legislature and its limited mandate to deal with limited questions of coordinating foreign and economic policy 
would make it an undesirable career choice for republic politicians. Simply put, upand-coming leaders would likely bypass such a body, preferring instead to build their careers within more powerful republic-level institutions.

But if, as American politicians frequently say, all politics is local politics, what are the prospects for legislative institutions at the republic level? In one sense, these prospects are far brighter; power has shifted to the republic level, but this is not to say that it will be lodged in the legislative as opposed to the executive branches of government. The republic level legislatures will suffer from many of the same weaknesses that bedeviled their all-union counterparts: absence of a tradition of legislative power and activism, the weakness of party organizations both within and external to the legislature, the loss of the issue of independence and the center's misdeeds as a rallying cry for local forces, and the tendency for the newly created republican presidencies to enlarge the powers of their offices. In one sense, they may face the worst of all possible worlds, at least in the immediate future. Pressured by newly mobilized voters and held responsible for the success or failure of a market economy which they created but cannot control, they may increasingly hand over de facto power to the regional presidents, much as the all-union Congress of People's Deputies and the Supreme Soviet had done before the coup attempt. To be sure, they will cling to the power to criticize and to second-guess, and they may be able to nullify certain actions by the executive branch. But such powers are a far cry from the ability to govern effectively.

Leadership will come from the newly created all-union presidency or from the republic presidencies. Before the coup attempt, the possibility existed that effective leadership might have emerged through the newly created all-union presidency, with the chief executive taking the lead in terms of providing policy guidance, initiating important legislation, and winning support within the legislature to secure the passage of key enactments. In this scenario, both leadership and coordination would transcend the partisan divisions of parties and groups noted above; presidents would be "above politics," at least in the sense that their popularity, national mandate (once directly elected), and real or potential powers as president would make them an independent force to be reckoned with.

Many of the powers of the new presidency were intended to set it apart from the day-to-day fray of the legislature and to provide mechanisms through which the chief executive could guide and/or intervene in the workings of a divided Supreme Soviet and Congress of People's Deputies (Pravda 16 March 1990). While the list of such powers was long and the implications of their real or threatened use now never fully shall be known, a brief summary suggests the potential that might have developed. Although legislative confirmation was required, the president had de facto control over the identity of the premier and significant, probably controlling influence over the selection of the cabinet; the president could request that the legislature conduct public referenda on significant policy issues and enjoyed important if not exclusive advantages in shaping the definition of issues and mobilizing public opinion; the president could issue decrees that had the binding 
effect of legislation, although their faithful implementation by federal and local officials always remained in doubt; the president could impose, or threaten to impose, states of emergency or initiate direct presidential rule, although legislative approval eventually was required; the president could mediate significant differences between the two houses of the Supreme Soviet and, in the event such mediation failed, propose to the Congress of People's Deputies the selection of a new Supreme Soviet from among its membership, thus giving him the de facto power to dissolve the more important legislative body; and once popularly elected, the president would have spoken with a clear national mandate, both because of the nature of the electoral mechanism itself (a successful candidate would have received over fifty percent of the total vote cast in the nation as a whole and also over fifty percent in a majority of the union republics) and because of the likelihood of continuing factionalism within the legislature itself.

But even before the coup attempt, the presidency failed to exercise strong national leadership. The threatened use of referenda and presidential decrees to bypass the legislature had little impact in terms of pulling a recalcitrant Supreme Soviet or Congress of People's Deputies into line. The mechanism for referenda could be employed sparingly, at best, and the use of presidential decrees to impose direct control proved ineffective as both federal and local authorities largely ignored Gorbachev's directives. The more drastic powers of direct presidential rule or the declaration of a state of emergency proved politically impossible to bring to bear because of the threat of widespread public opposition, especially in the non-Russian areas. To the extent that Gorbachev imposed his will on the dual levels of the legislature, it either was through the voting strength of the party's parliamentary bloc and its informal allies -- the so-called "aggressively obedient majority" -- or through the legislature's own willingness to give greater emergency powers to the presidency.

Much of the pre-coup challenge to Gorbachev's rule was extra-parliamentary in nature. It is important to recall that his most strident critics largely remained outside existing party structures. Most visible, of course, was Boris Yeltsin, who avoided formal affiliation with any party since his dramatic resignation from the CPSU. Much as in American politics, where the presidential party organization is separate from and frequently at odds with congressional party leadership, Soviet politics seemed already to be developing a dual-track political life. While in one sense such dualism insulated the chief executive from the problems of day-to-day legislative affairs, it also diminished his ability to exercise leadership at this level except through the indirect mechanisms and left him dependent on the nature of his office as a bully pulpit, neither of which proved effective even before the coup.

The attempted coup dramatically changed the role of the all-union presidency. Having ignored repeated warnings that a coup attempt was imminent, Gorbachev emerged from the two days of house arrest at Foros more as a victim of his own shortsightedness than as a triumphant leader returning to the seat of government. In contrast, Yeltsin's successful defiance elevated him to the stature of a national hero, 
capable of challenging Gorbachev for de facto leadership. The interim arrangements cobbled together shortly after the coup reflected a tacit standoff between the two leaders. Gorbachev, now shorn of his reputation as a political survivor, remained de jure president of his "aggressively obedient majority" in the legislature, and of the institutional constituency of the Communist Party that he virtually ordered out of existence. Real power now lay with the republican presidents, whose willing participation in the State Council masked both significant political differences and their own private desires to exploit a moment of weakness at the center to institutionalize and perpetuate the emasculation of the all-union government. Sometimes with near consensus (the best examples of which are the ten-republic agreement for economic cooperation and the draft of a new union treaty) and sometimes with obvious dissensus (the Slavic republican presidents' agreement to form a commonwealth, and the Central Asian presidents' protest of their exclusion come to mind), these presidents increasingly have preempted the mediating role once intended for the all-union presidency. The creation of the Commonwealth of Independent States and the abolition of the all-union presidency have not so much ended the war of presidents as they have transformed it into a multisided competition among the presidents of the now independent states that have joined the new association. It is clear that while the republic presidents have taken unto themselves many of the powers of the central government, they also have inherited many of the same problems that made it unable to rule. With little real power to govern effectively even within their own republics, with the potential for serious differences over the nature of the future association of the sovereign republics, and with increasingly fragmented legislatures and parties, these presidents will quickly learn that they have much in common with Gorbachev.

\section{REFERENCES}

Brovkin, Vladimir. 1990. Revolution from Below: Informal Political Associations in Russia, 1988-1989. Soviet Studies 42: 233-257.

Economist, The. 24 November 1990.

Foye, Steven. 1990. U.S. Congressional Report on Soviet Committee for Defense and State Security. Radio Liberty 2 (11 May): 6-8.

Gorbachev, Mikhail S. 1987. Perestroika: New Thinking for Our Country and the World. New York: Harper and Row.

Gruber, Anne M. 1990. Political Parties and Groups in the U.S.S.R. New Outlook 1: 2938.

Izvestiia. 5 June 1989.

Mann, Dawn. 1990. Gorbachev Sworn in as President. Radio Liberty 2 (23 March): 1-4. McFaul, Michael. 1991. The Social Democrats and Republicans Attempt to Merge. Radio Liberty 3 (18 January): 6-9. 


\section{Gorbachev's Democratic Revolution}

Meerovich, Aleksandr. 1990. Soviet Draft Law on Public Associations Makes Slow Progress. Radio Liberty 2 (13 July): 6-8.

- 1990. The Emergence of Russian Multiparty Politics. Radio Liberty 2 (24

August): 8-16.

Pravda. 6 February 1990, 16 March 1990, 21 June 1990, and 16 October 1990.

Rahr, Alex ander. 1990. Inside the Interregional Group. Radio Liberty 2 (26 October): 1 4.

Senn, Alfred Erich. 1990. Lithuania Awakening. Berkeley: University of California Press. Teague, Elizabeth. 1990. The Powers of the Soviet Presidency. Radio Liberty 2 (23 March): 4-7. and Vera Tolz. 1990. Moves to Create a Russian Communist Party. Radio Liberty 2 (11 May): 1-3. . 1991. The CPSU R.I.P. Radio Liberty 3 (22 November ): 1-8.

Tolz, Vera. 1987. Informal Groups Hold First Officially Sanctioned Conference. Radio Liberty (23 September). 1988. Informal Groups in the USSR in 1988. Radio Liberty (30 October). . 1989. Informal Groups in Soviet Politics in 1989. Radio Liberty 1 (24 November): 4-7. - 1990. A New Approach to Informal Groups. Radio Liberty 2 (9 March): 1-3. - 1990. The Emergence of a Multiparty System in the USSR. Radio Liberty 2 (27 April): 4-6.

. 1991. The Congress of Democratic Forces: Soviet Democrats Make Another Attempt to Unite. Radio Liberty 3 (8 February): 6-8.

Tsypkin, Mikhail. 1990. The Committee for Defense and State Security of the Supreme Soviet. Radio Liberty 2 (11 May): 8-11.

USSR This Week, The. 1991. Radio Liberty 3 (24 January): 61.

Vardys, V. Stanley. 1989. Lithuanian National Politics. Problems of Communism 38 (July-August): 53-76.

Vremya. 24 December 1990. 